\title{
GAP-43 Is Critical for Normal Development of the Serotonergic Innervation in Forebrain
}

\author{
Stacy L. Donovan, ${ }^{1}$ Laura A. Mamounas, ${ }^{3,4}$ Anne M. Andrews, ${ }^{5}$ Mary E. Blue, ${ }^{2,3,6}$ and James S. McCasland ${ }^{1}$ \\ ${ }^{1}$ Department of Cell and Developmental Biology, State University of New York Upstate Medical University, Syracuse, New \\ York 13210, ${ }^{2}$ Departments of Neurology and ${ }^{3}$ Neuroscience and ${ }^{4}$ Division of Neuropathology, Johns Hopkins University \\ School of Medicine, Baltimore, Maryland 21205, ${ }^{5}$ Department of Chemistry, The Pennsylvania State University, University

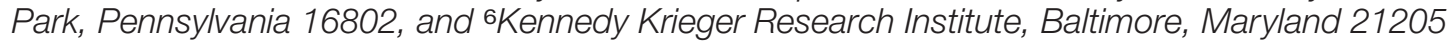

\begin{abstract}
Serotonergic (5-HT) axons from the raphe nuclei are among the earliest afferents to innervate the developing forebrain. The present study examined whether GAP-43, a growth-associated protein expressed on growing 5-HT axons, is necessary for normal 5-HT axonal outgrowth and terminal arborization during the perinatal period. We found a nearly complete failure of $5-\mathrm{HT}$ immunoreactive axons to innervate the cortex and hippocampus in GAP-43-null (GAP43-/-) mice. Abnormal ingrowth of $5-\mathrm{HT}$ axons was apparent on postnatal day $0(\mathrm{PO})$; quantitative analysis of P7 brains revealed significant reductions in the density of $5-\mathrm{HT}$ axons in the cortex and hippocampus of GAP43-/- mice relative to wild-type (WT) controls. In contrast, 5-HT axon density was normal in the striatum, septum, and amygdala and dramatically higher than normal in the thalamus of GAP43-/- mice. Concentrations of serotonin and its me-
\end{abstract}

Serotonergic (5-HT) neurons in the raphe nuclei are generated very early in ontogeny. They play a key role in a variety of developmental brain processes, ranging from cell differentiation to proliferation and migration. Abnormalities in 5-HT innervation have been implicated in a number of neuropsychiatric disorders including depression, anxiety, schizophrenia, and autism (Baumgarten and Grozdanovic, 1995; Hen, 1996; Mann, 1998).

Serotonin cells are generated between embryonic day 11 (E11) and E15 (Lidov and Molliver, 1982a; Wallace and Lauder, 1983). 5-HT axons reach the telencephalic anlage via the median forebrain bundle before birth and send branches to selected forebrain areas, including the cerebral cortex and the hippocampal formation (Lidov and Molliver, 1982b; Wallace and Lauder, 1983; Rubenstein, 1998). Preterminal 5-HT axons enter directly into the marginal and intermediate zones of the immature cortex, forming a bilateral pattern at the medial, frontal, and lateral edges of the cerebral hemisphere. Terminal field development proceeds

Received Dec. 14, 2001; revised Dec. 14, 2001; accepted Jan. 28, 2002.

This work was supported by National Institutes of Health (NIH) Grants NS31829 and NS40779 and National Science Foundation Grant IBN-9724102 to J.S.M. and NIH Grants HD24448, HD24061, HD24605, and ES08131 to M.E.B. We thank Drs. Donna Maier and W. Ernest Lyons for expert guidance, Karen Smith-Connor for assistance with the densitometric analysis, Angela Chisnell for assistance with the neurochemical determinations, and Mary S. Lange for assistance with the computer graphics.

Correspondence should be addressed to Dr. Mary E. Blue, Kennedy Krieger Research Institute, 707 North Broadway, Baltimore, MD 21205. E-mail: blue@kennedykrieger.org.

L. A. Mamounas' present address: Repair and Plasticity Program, National Institute of Neurological Disorders and Stroke/National Institutes of Health, Bethesda, MD 20892-9525.

Copyright $\odot 2002$ Society for Neuroscience $0270-6474 / 02 / 223543-10 \$ 15.00 / 0$ tabolite, 5-hydroxyindolacetic acid, and norepinephrine were decreased markedly in the anterior and posterior cerebrum but increased in the brainstem of GAP43-/- mice. Cell loss could not account for these abnormalities, because unbiased stereological analysis showed no significant difference in the number of 5-HT dorsal raphe neurons in P7 GAP43-/- versus WT mice. The aberrant 5-HT innervation pattern persisted at P21, indicating a long-term alteration of 5-HT projections to forebrain in the absence of GAP-43. In heterozygotes, the density and morphology of 5-HT axons was intermediate between WT and homozygous GAP43-/- mice. These results suggest that GAP-43 is a key regulator in normal pathfinding and arborization of 5-HT axons during early brain development.

Key words: serotonin; terminal arborization; neocortex; hippocampus; GAP-43; denervation; knock-out mice

as 5-HT axons fill in the cortical plate. 5-HT axon density increases in the cerebral cortex and hippocampus during the first three postnatal weeks until an adult innervation pattern is achieved.

Despite numerous studies on the ontogeny of 5-HT innervation, the factors that regulate 5-HT axon outgrowth and terminal arborization remain largely unknown. One possible factor is S-100 $\beta$, a protein secreted by astrocytes, which acts as a guidance molecule for the migration of raphe neurons (Van Hartesveldt et al., 1986). S-100 $\beta$ functions as a 5-HT growth factor in vitro by inducing 5-HT sprouting (Azmitia et al., 1990; Haring et al., 1993). Another candidate factor is brain-derived neurotrophic factor (BDNF), which stimulates 5-HT axonal growth in the adult neocortex (Mamounas et al., 1995, 2000). However, the development of 5-HT projections from the raphe nuclei is apparently normal in BDNF knock-out mice (Lyons et al., 1999).

Another endogenous factor that may regulate the developmental ingrowth of 5-HT axons is the growth-associated protein GAP-43. GAP-43 is a protein expressed in early development (Jacobson et al., 1986; Neve et al., 1987; Erzurumlu et al., 1990) and has a role in axonal pathfinding (Strittmatter et al., 1995; Kruger et al., 1998; Sretavan and Kruger, 1998), neurotransmitter release (Dekker et al., 1989a,b; Haruta et al., 1997; Neve et al., 1998), and synaptic plasticity (Lovinger et al., 1986; Linden et al., 1988; Gianotti et al., 1992; Ramakers et al., 1995; Benowitz and Routtenberg, 1997). GAP-43 is widely expressed in the rat forebrain (Jacobson et al., 1986; Oestreicher and Gispen, 1986; Benowitz et al., 1988; McGuire et al., 1988), and displays a high level of expression in monoaminergic neurons (Bendotti et al., 1991; 
Wotherspoon et al., 1997). Moreover, after surgical lesion of the medial forebrain bundle, GAP-43 expression is increased in regenerating monoaminergic axons (Alonso et al., 1995).

In the present study, we used mice with a targeted disruption of the GAP-43 gene (both homozygous GAP43-/- and heterozygous GAP43+/- mice) to investigate the role of GAP-43 in the development of 5-HT innervation to forebrain. We have shown previously that GAP43-/- mice fail to develop whisker-related barrels or an ordered whisker map in the somatosensory (SI) cortex (Maier et al., 1999). We report here that neonatal and juvenile GAP43-/- mice also show an aberrant 5-HT innervation.

\section{MATERIALS AND METHODS}

All procedures for animal use were reviewed and approved by the Animal Care and Use Committee at State University of New York Upstate Medical University. The GAP43-/ $(n=36)$, GAP43+/- $(n=$ 24 ), and wild-type (WT; $n=37$ ) mice used for this study were generated as described previously (Maier et al., 1999). All mice were the progeny of a seventh-generation backcross into the C57BL/6 strain.

Serotonin neurotransmitter and transporter immunohistochemistry. Mice at postnatal day $0(\mathrm{P} 0)(n=4 \mathrm{WT} ; n=4 \mathrm{GAP} 43+/-; n=3 \mathrm{GAP} 43-1$ $-)$, P7 ( $n=10 \mathrm{WT} ; n=5 \mathrm{GAP} 43+/-; n=10 \mathrm{GAP} 43-/-)$, and P21 $(n=7 \mathrm{WT} ; n=5 \mathrm{GAP} 43+/-; n=7 \mathrm{GAP} 43-/-)$ were perfusion-fixed, and their brains were prepared for immunocytochemical localization of serotonin or the serotonin transporter (SERT) as reported previously (Mamounas et al., 1995). Mice were anesthetized with isoflurane, weighed, and perfused transcardially with PBS followed by $4 \%$ paraformaldehyde in $0.15 \mathrm{~m}$ phosphate buffer, $\mathrm{pH} 7.4$; flow volume and rate varied with age. Brains were removed, weighed, and post-fixed in the same paraformaldehyde solution for 4-5 hr. After post-fixation, brains were cryoprotected in $30 \%$ sucrose in PBS and stored at $-70^{\circ} \mathrm{C}$ before immunocytochemical processing. Brain and body weights were calculated at P7 ( $n=33 \mathrm{WT} ; n=45 \mathrm{GAP} 43+/-; n=16 \mathrm{GAP} 43-/-)$ and at P21 $(n=19 \mathrm{WT} ; n=24 \mathrm{GAP} 43+/-; n=15 \mathrm{GAP} 43-/-)$. Two-tailed $t$ tests revealed that brain and body weights of GAP43-/- mice were significantly less than they were in WT and GAP43+/- mice at P7 and P21 $(p<0.001)$. At P21, brain and body weights of GAP43+/- mice were also significantly less than they were in WT mice $(p \leq 0.01)$. However, standard curve analysis revealed that in all genotypes, the ratio of brain to body weight was proportional at both P7 and P21.

Coronal and parasagittal sections (cut at $40-50 \mu \mathrm{m}$ ) were stained as described previously (Mamounas et al., 1991, 1995). Free-floating sections were incubated for $1 \mathrm{hr}$ in blocking solution (10\% normal goat serum, $0.3 \%$ Triton $\mathrm{X}-100,5 \%$ nonfat dry milk in PBS), followed by incubation with anti-serotonin or SERT antibodies (Diasorin, Stillwater, MN) diluted 1:12,500 in blocking solution for $48 \mathrm{hr}$ at $4^{\circ} \mathrm{C}$. Sections then were processed by the avidin-biotin complex (ABC) method, which included a $1 \mathrm{hr}$ incubation in biotinylated goat anti-rabbit (1:200) followed by a 30 min incubation in ABC (1:50; Vector Laboratories, Burlingame, CA). The tissue was then reacted with a diaminobenzidine (DAB) tetrachloride solution for 10-15 min. Sections were mounted on chrom-alum subbed slides and allowed to dry overnight. The DAB reaction product was subsequently enhanced using a silver-gold enhancement protocol (Kitt et al., 1985). Slides were incubated in $1.42 \%$ silver nitrate (Sigma, St. Louis, MO) solution at $56^{\circ} \mathrm{C}$ for $1 \mathrm{hr}$ on a shaking water bath. After a 15 min rinse in running deionized water, the slides were incubated in the dark in a $0.2 \%$ gold chloride (Sigma) solution for $10 \mathrm{~min}$ at room temperature. Slides were then rinsed and dipped in a 5\% sodium thiosulfate (Sigma) solution for $5 \mathrm{~min}$, followed by a final rinse in deionized water. All glassware used in this procedure was cleaned with UltraClean (Krackeler Scientific, Albany, NY) $24 \mathrm{hr}$ before the procedure.

Axon density analysis. The density of 5-HT immunoreactive axons was measured in coronal sections immunostained at P7 $(n=7 \mathrm{WT} ; n=4$ GAP43 $+/-; n=7$ GAP43 $-/-)$ for serotonin or at P21 $(n=7 \mathrm{WT} ; n=$ 5 GAP43 $+/-; n=7$ GAP43-/-) for SERT or serotonin, as described previously (Mamounas et al., 2000). Patterns and density of SERT and serotonin immunostaining were identical in the P21 tissue. Briefly, pixel density was measured in two to three different microscope fields per region per animal, using a $20 \times$ objective attached to a CCD camera to capture a live image. The regions measured included the frontal cortex, piriform cortex, amygdala, medial septum, striatum, thalamus, and hippocampus. In the hippocampus, the three subfields, CA1, CA3, and dentate gyrus, were measured independently. All data were normalized relative to the averaged data obtained in WT controls and analyzed using single-factor ANOVA and descriptive statistics.

Unbiased cell counts of 5-HT neurons in the raphe nuclei. Coronal sections (cut at $40 \mu \mathrm{m}$ ) that were processed for serotonin immunostaining and counterstained with cresyl violet were used to perform cell counts of 5-HT neurons in the dorsal raphe at P7. The section thickness after processing ranged from 12 to $16 \mu \mathrm{m}$. An observer who was blinded to the genotype of each animal ( $n=8 \mathrm{WT} ; n=8 \mathrm{GAP} 43-/-)$ performed the analysis. For unbiased sampling, the Optical Fractionator method (Stereo Investigator version 3.0; MicroBrightField, Inc., Colchester, VT) was used. A starting section was randomly selected preceding the location of the rostral dorsal raphe, and every other section through the dorsal raphe nucleus (to the level of the locus ceruleus) was measured. For the analysis, a $40 \times 40 \mu \mathrm{m}$ counting frame, a $1 \mu \mathrm{m}$ guard, a $130 \times 130 \mu \mathrm{m}$ sampling grid, and a dissector height of $10 \mu \mathrm{m}$ was used.

HPLC. HPLC coupled with electrochemical detection was used to determine levels of serotonin and its metabolite 5-hydroxyindolacetic acid (5-HIAA), dopamine and its metabolites 3,4-dihydroxyphenylacetic acid and homovanillic acid, and norepinephrine. Homogenized brain tissue samples from P7 WT, GAP43+/-, and GAP43-/- mice were analyzed from three different brain regions, the anterior cerebrum, posterior cerebrum, and brainstem, by methods described previously (Andrews et al., 1996). Tissue samples of the anterior cerebrum included the frontal and parietal cortex, dorsal hippocampus, and striatum; samples of the posterior cerebrum included the parietal and occipital cortex and ventral hippocampus; brainstem samples included the midbrain and pons. Raw data were normalized with respect to WT neurotransmitter concentrations $(100 \%)$ in WT controls $(n=8 \mathrm{WT} ; n=10 \mathrm{GAP} 43+/-$; $n=8$ GAP43-/-).

\section{RESULTS}

\section{Severe decreases in 5-HT axon density and levels of serotonin in selected forebrain areas of perinatal GAP43-/- mice}

In WT mice, 5-HT axons were distributed throughout the brain by the day of birth (P0) (Fig. $1 A$ ). The density of 5-HT axons was especially high in the parietal cortex (Fig. $1 A$ ), consistent with the known high innervation densities in sensory areas (somatosensory and visual) in the rat (Lidov and Molliver, 1982b; D'Amato et al., 1987; Rhoades et al., 1990; Dori et al., 1996). In homozygous GAP43-/- mice, however, the entire cortex and hippocampus were nearly devoid of 5-HT axons at this age (Fig. 1C). Heterozygous GAP43+/- mice exhibited an intermediate phenotype, with apparently normal innervation densities in subcortical regions but decreased 5-HT axonal ingrowth in the cortex and hippocampus (Fig. 1B).

Between $\mathrm{P} 0$ and $\mathrm{P} 7$, the density of 5-HT axons in the striatum of WT mice did not change significantly (Fig. 1D). However, the density of 5-HT axons increased in the thalamus, cortex, and hippocampus of WT mice between P0 and P7. At P7, distinct patches of serotonin immunoreactivity were visible in layer IV of the parietal cortex (Figs. $1 D, 2 A, B$, arrows; $3 A$ ), as has been well characterized in the rat. In GAP-43-null mice, the 5-HT innervation remained sparse in the cortex and hippocampus at P7 (Figs. $1 F, 2 C, D, 3 C$ ). A limited number of 5-HT axons did innervate the ventral and lateral portions of the cortex in GAP43-/- mice but appeared to stop abruptly after entering the parietal cortex at the level of the barrel field (Figs. 2C,D, arrows). The density of 5-HT axons in the cortex and hippocampus of GAP43+/- mice was intermediate between that in WT and GAP-43-null mice, especially in more caudal regions of the cortex (Figs. 1E, 3B).

Quantitative densitometric analysis at $\mathrm{P} 7$ revealed a $>70 \%$ decrease in 5-HT axon density in the frontal cortex and an $80 \%$ reduction in the hippocampus of GAP43-/- mice compared with 
PO
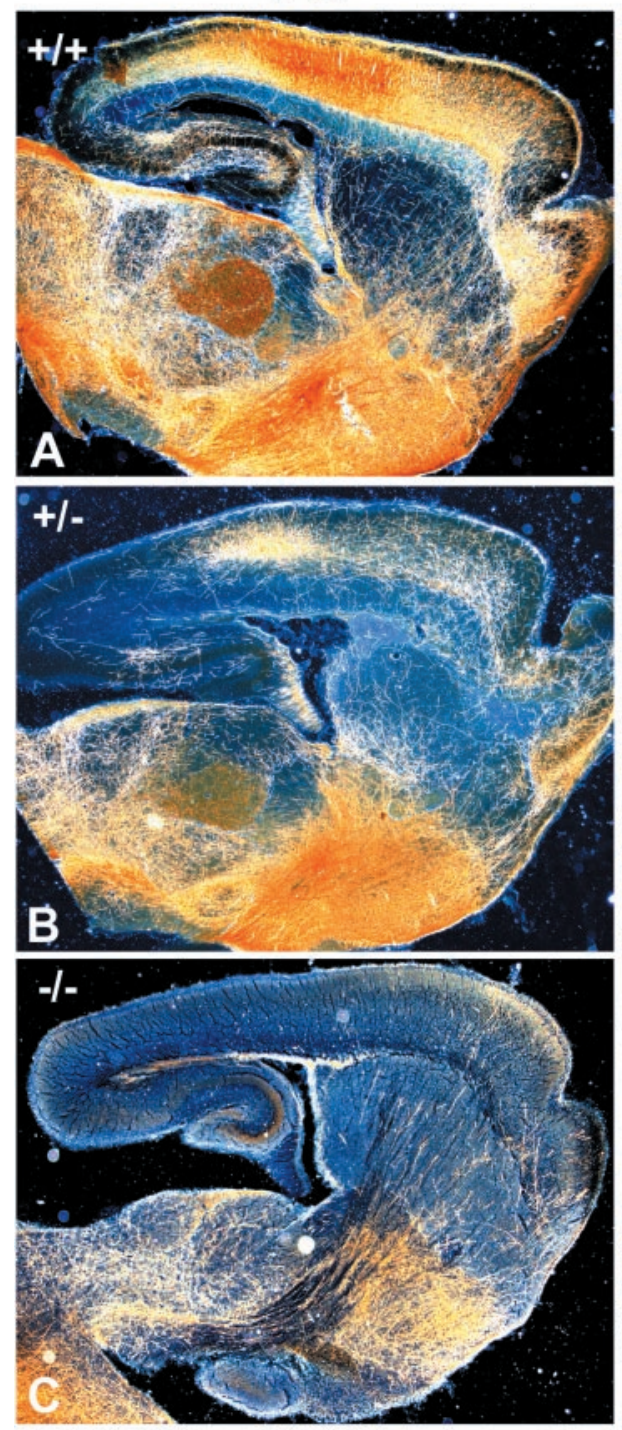

\section{P7}
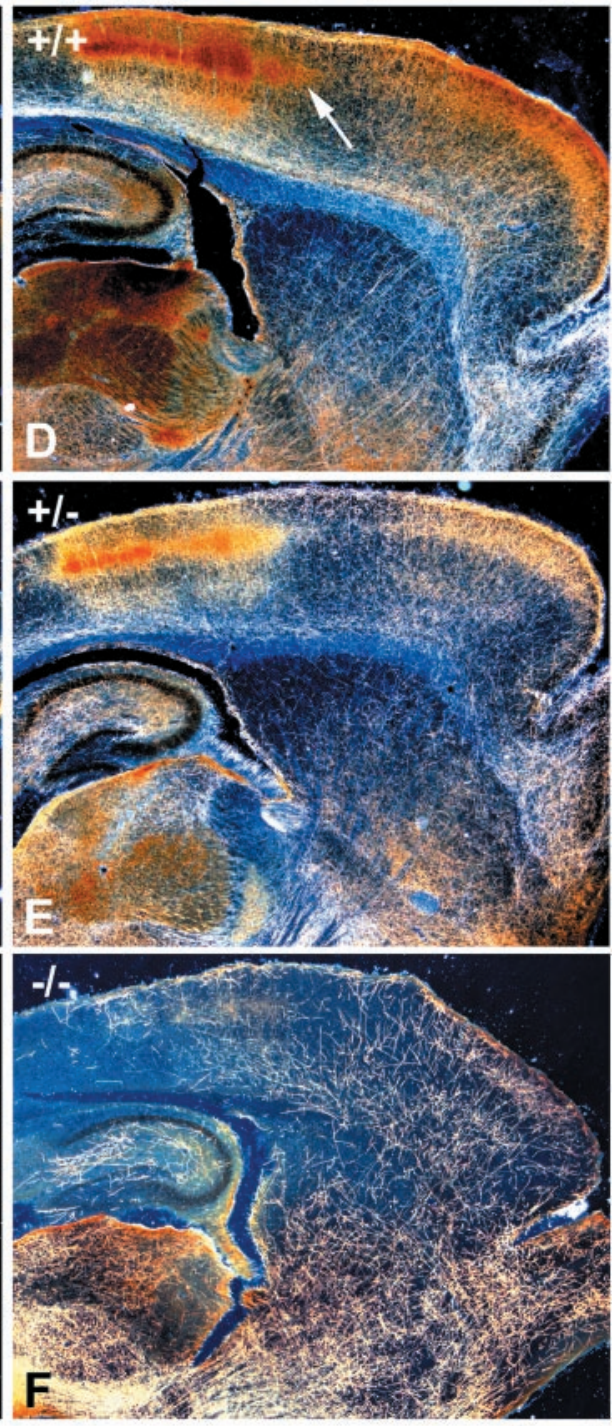

$\overline{500 \mu \mathrm{m}}$
Figure 1. 5-HT axons fail to innervate the cortex and hippocampus in neonatal GAP43-/- mice. Low-magnification darkfield photomicrographs of parasagittal sections from $\mathrm{P} 0(A-C)$ and $\mathrm{P} 7(D-F)$ mice show bright serotonin-immunoreactive axons on a dark background. At P0, 5-HT axons in WT mice are present throughout the brain and densely innervate the thalamus, basal forebrain, and frontal and parietal areas of the cortex $(A)$. The density of 5-HT axons in GAP43-/- mice is dramatically reduced in most brain regions compared with WT mice at $\mathrm{P} 0(C)$. The density of 5-HT axons increases in the thalamus, cortex, and hippocampus of WT mice over the next week. At P7, distinct patches of serotonin immunoreactivity are visible in layer IV of the parietal cortex (arrow, $D$ ). In GAP43-/- mice at P7, the density of 5-HT axons in subcortical regions is similar to that in WT mice, but very few 5-HT axons are observed in the cortex and hippocampus $(F)$. In GAP43+/- mice at $\mathrm{P} 0(B)$ and $\mathrm{P} 7(E)$, 5-HT axon density in the hippocampus and cortex is intermediate between that in GAP43-/- and WT mice. Scale bar, $500 \mu \mathrm{m}$.
WT mice $(p<0.001)$ (Fig. 4A). 5-HT axon density in the piriform cortex also was decreased significantly compared with WT mice $(p<0.05)$, but less markedly than in other areas $(20 \%$ reduction) (Fig. 4A). Axon density measures in the striatum, septum, and amygdala in GAP43-/- mice were not significantly different from the WT (Fig. 4A).

Levels of serotonin and its metabolite 5-HIAA and norepinephrine were measured by HPLC in three different brain regions: the anterior and posterior cerebrum and the brainstem of P7 WT, GAP43+/-, and GAP43-/- mice. Mice with varying levels of GAP-43 showed a gene-dose-dependent decrease in serotonin, 5-HIAA, and norepinephrine in the anterior and posterior regions of the cortex (Fig. 5), consistent with the immunocytochemical analysis. HPLC measurements did not show statistically significant changes in levels of dopamine or its metabolites, 3,4-dihydroxyphenylacetic acid and homovanillic acid, in the brain regions examined (data not shown). Interestingly, levels of serotonin, 5-HIAA, and norepinephrine were significantly increased in the brainstem region of GAP43-/ - mice $(p<0.01)$ (Fig. 5).

\section{No change in the number of 5-HT neurons in the dorsal raphe of GAP43-/- mice}

To determine whether the loss of 5-HT axonal ingrowth into the cortex and hippocampus resulted from a reduced number of 5-HT cell bodies, we counted 5-HT neurons in the dorsal raphe nuclei of P7 WT and GAP43-/- mice. Using an unbiased counting method (Optical Fractionator), we found no significant difference $(p=0.086)$ in the numbers of 5-HT cell bodies between the two genotypes (WT, $5651 \pm 456$; GAP43-/-, $4512 \pm 424$ ). Moreover, 5-HT neurons in the dorsal raphe of WT and GAP43-/mice did not appear to be morphologically distinguishable with qualitative examination. These results indicate that GAP-43 affects primarily 5-HT axonal pathfinding and not cell differentiation.

\section{5-HT axons fail to innervate the forebrain of GAP43-/- mice at P21}

By the end of the third postnatal week (P21), 5-HT axons in WT mice showed a relatively uniform distribution across most cortical layers, similar to the adult 5-HT innervation pattern (Figs. 3D, 

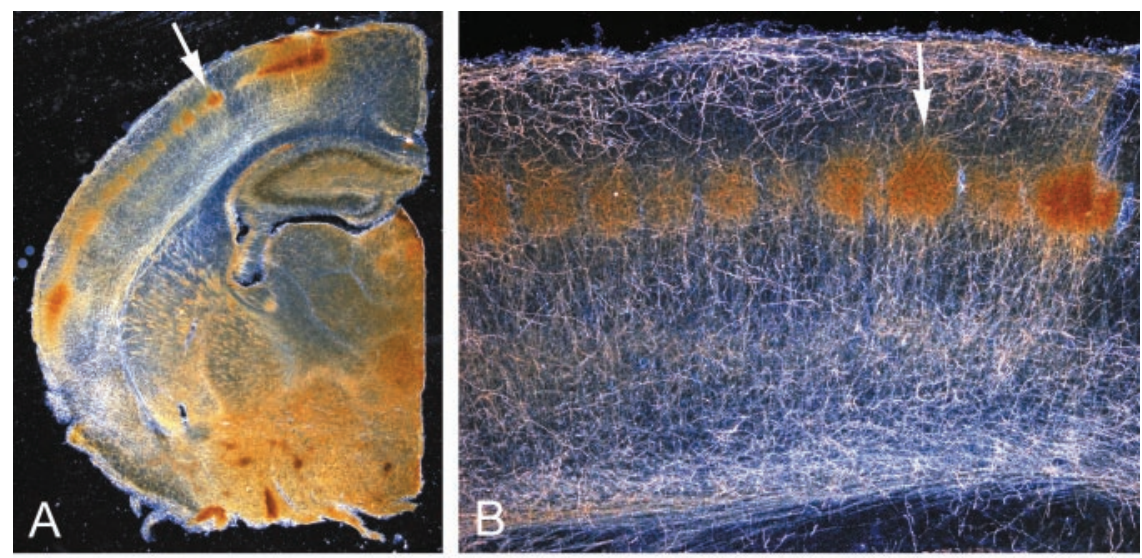

Figure 2. The outgrowth of 5-HT axons to the dorsal neocortex and hippocampus falters in the absence of GAP-43. Dark-field photomicrographs show the distribution of 5-HT axons in coronal sections from P7 mice; arrows demarcate the same regions in low- and high-magnification views. In WT mice $(A, B)$, 5-HT axons are present throughout the brain and densely innervate the thalamus, basal forebrain, hippocampus, and cortex. Distinct patches of serotonin immunoreactivity that demarcate barrels in layer IV of the parietal cortex are visible (arrows in $A, B$ ). In GAP43-/- mice $(C, D)$, the growth of 5-HT axons into subcortical regions is relatively normal, but only a few 5-HT axons are observed beyond the ventral aspects of the neocortex.
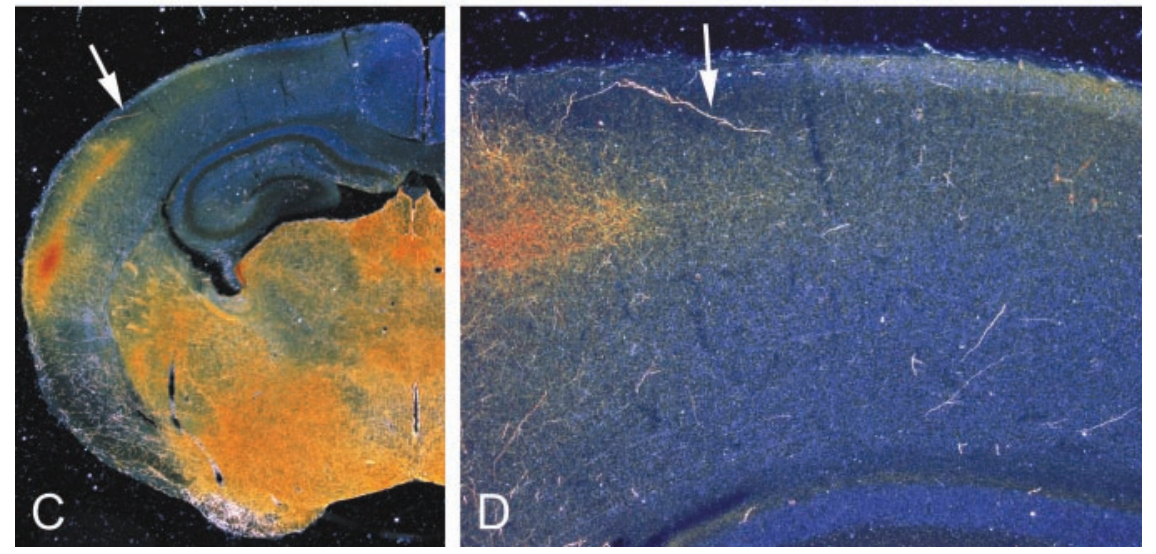

$6 A$ ). The frontal cortex continued to show higher innervation densities than the more caudal occipital cortex. Many fine 5-HT axon terminals were present in both cortical and hippocampal regions of WT mice (Figs. 3D, 6A,D). At P21 in GAP43-/mice, the 5-HT innervation of the dorsal neocortex and hippocampus (Figs. $3 F, 6 C, E$ ) remained very sparse compared with WT controls. Relative to $\mathrm{P} 0$ and $\mathrm{P} 7$ in these mutant mice, a few more 5-HT axons were observed in the frontal cortex (Fig. 6C) and hippocampus (Fig. $3 F$ ) by P21. However, most of the 5-HT axons present in GAP43-/- mice were thick and unbranched, with a preterminal morphology (Fig. 6E).

Quantitative analysis of the P21 material revealed a continued reduction in 5-HT axon density in the cortex ( $82 \%$ decrease) and hippocampus (62\% decrease) of GAP43-/ - mice relative to WT controls $(p<0.0001)$ (Fig. 4B). As at P7, the striatum and amygdala still exhibited a normal density of 5-HT axons at P21. However, in the septum of GAP43-/- mice at P21, the 5-HT innervation density was decreased by $20 \%$ compared with WT, unlike the normal density seen at P7 in these mutant mice $(p<$ 0.001) (Fig. 4B). In GAP43+/- mice, abnormalities in the 5-HT innervation were intermediate between those of WT and GAP43-/- animals in terms of both axon density and morphology (Figs. 3E, 6B). These data suggest that GAP-43 plays a continued role in 5-HT axon pathfinding and terminal arborization in juvenile mice.

\section{Increased 5-HT axon density in ventrobasal thalamus of GAP-43-null mice}

In light of the abnormalities in thalamocortical circuitry seen in GAP-43-null mice (Maier et al., 1999), we examined the devel- opment of 5-HT innervation to the ventrobasal (VB) complex in these mice. Neurons in the VB thalamus project to the barrel field in the somatosensory cortex and are arranged in a whisker-specific or "barreloid" pattern. Because of the transient expression of SERT, barreloids and thalamocortical axons (TCAs) leaving the thalamus are serotonin-positive in newborn rodents, a pattern that continues until the second or third postnatal week (Bennett-Clarke et al., 1996; Cases et al., 1996). Likewise, at P7, barreloids and TCAs were intensely serotonin-positive in WT mice (Fig. $7 A$ ) and heterozygous GAP43+/- mice (Fig. 7B). In contrast, serotonin-positive barreloids and TCAs were largely absent in GAP-43-null mice at $\mathrm{P} 7$ (Fig. $7 C$ ).

In normal rodents, serotonin-positive axons arising from the raphe nuclei project to the $\mathrm{VB}$ thalamus with a relatively low innervation density at P7. These raphe-thalamic 5-HT axons can be readily distinguished from thalamocortical 5-HT-positive axons by their morphology and their homogeneous distribution throughout the VB thalamus, as characterized in previous axonal tracing studies (Halaris et al., 1976; Moore et al., 1978; Kosofsky and Molliver, 1987; Molliver, 1987; Kirifides et al., 2001). Unexpectedly, we found in GAP-43-null mice a marked hyperinnervation of the VB thalamus by raphe 5-HT axons (Fig. 7C). Quantitative measurements at P7 showed that the density of 5-HT axons in the VB thalamus was 327\% higher in GAP43-/mice $(p<0.001)$ and $58 \%$ higher in heterozygote GAP43+/mice $(p<0.05)$ relative to WT controls (Fig. 8). The observed 5-HT hyperinnervation could be in part a result of a decrease in brain size found in GAP43-/- mice (Maier et al., 1999). However, the changes in brain size were relatively small $(17 \%)$ in 

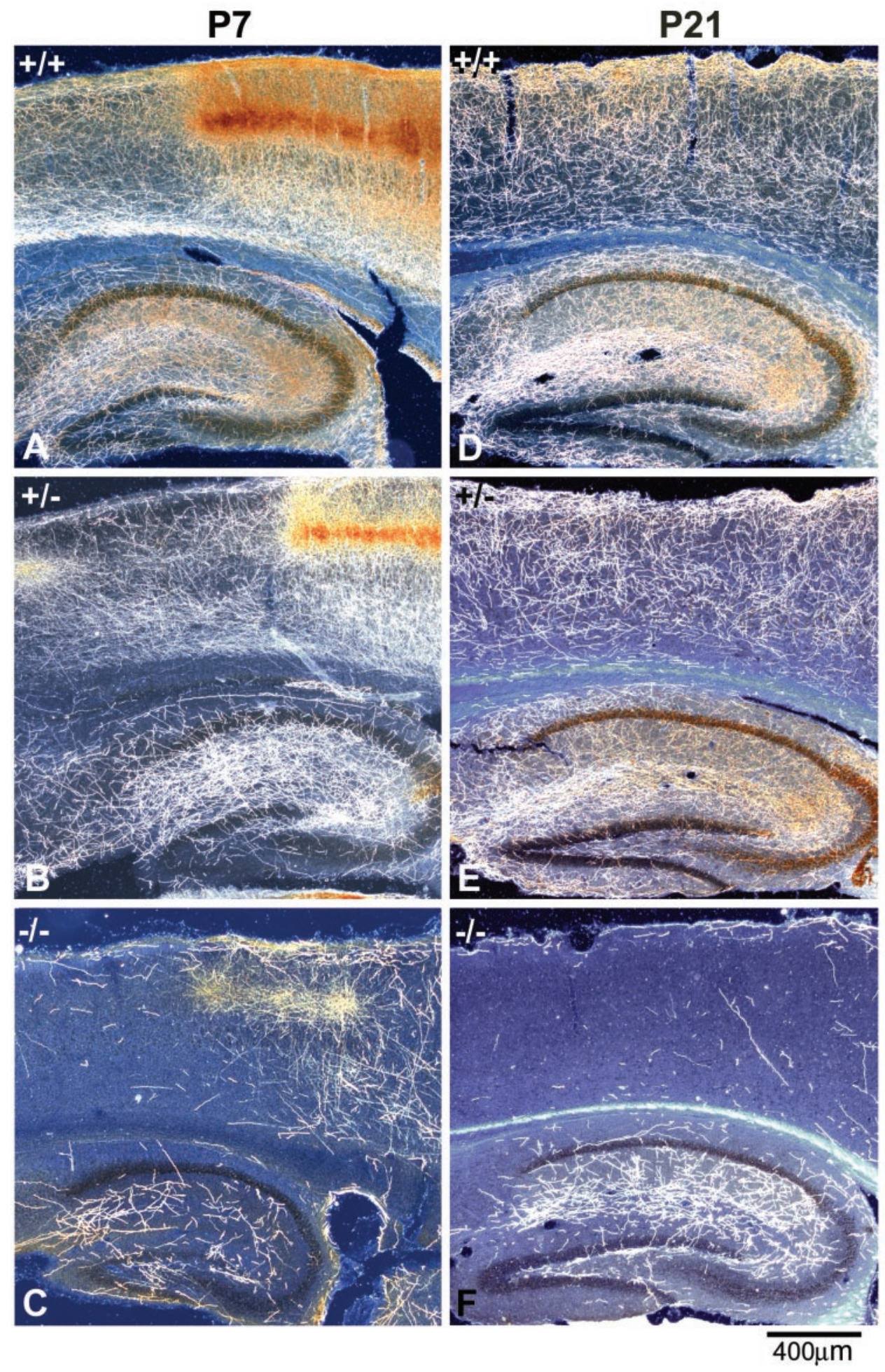

Figure 3. The cortex and hippocampus exhibit persistent deficits in 5-HT innervation in GAP43-/- and GAP43+/- mice. Dark-field photomicrographs of parasagittal sections show 5-HT $(A-C)$ and SERT $(D-F)$ immunostaining in the cortex and hippocampus of $\mathrm{P} 7(A-C)$ and $\mathrm{P} 21(D-F)$ mice. At P7, 5-HT axons densely innervate the cortex and hippocampus in WT mice (A). 5-HT immunoreactivity is especially dense in layer IV of the primary somatosensory cortex, where barrel-like patches are clearly visible ( $A$, right half). 5-HT axon density in layer IV of the primary somatosensory cortex of GAP43+/- mice at P7 $(B)$ is similar to that in WT animals, but other cortical layers and the hippocampus show reduced densities of 5-HT axons. Only a few 5-HT axons are present in the hippocampus and cortex of P7 GAP43-/mice $(C)$. At P21, 5-HT axons labeled with SERT show a dense and even distribution throughout all layers of the cortex and hippocampus in WT mice $(D)$. 5-HT innervation density in the cortex and hippocampus of GAP43+/- mice is less than that of WT mice at P21 $(E)$. The density of 5-HT axons in the cortex remains extremely low in GAP43-/- mice at P21 $(F)$. Scale bar, $400 \mu \mathrm{m}$. these mice and most likely do not account for the markedly greater ingrowth of 5-HT axons. This 5-HT hyperinnervation of the VB thalamus in GAP43-/- mice persisted to P21 (188\% of WT) (Fig. 8). However, as a result of the normal progressive ingrowth of 5-HT axons between P7 and P21 in the WT control mice (Fig. 7D) and heterozygote GAP43+/- mice (Fig. 7E), the hyperinnervation was less pronounced in juvenile (Figs. $7 F, 8$ ) than in newborn GAP43-/- mice.

\section{DISCUSSION}

\section{Regionally specific alterations in 5-HT innervation in the absence of GAP-43}

This study examined the development of 5-HT projections from raphe nuclei in genetically altered mice with reduced or no GAP-43 (GAP43-/- and GAP43+/-). Although 5-HT axons normally innervate most brain regions, the absence of GAP-43 


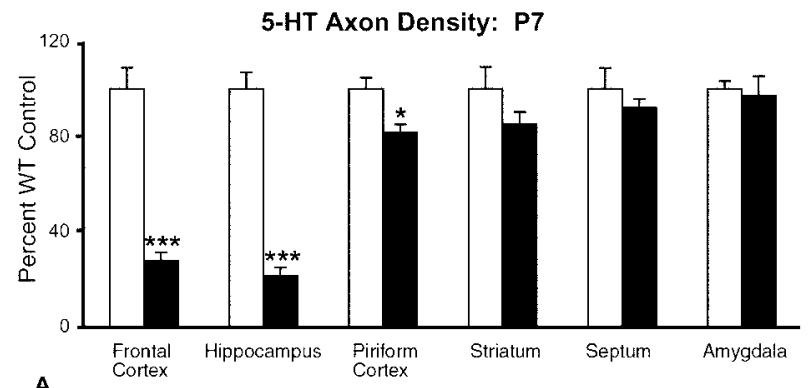

A

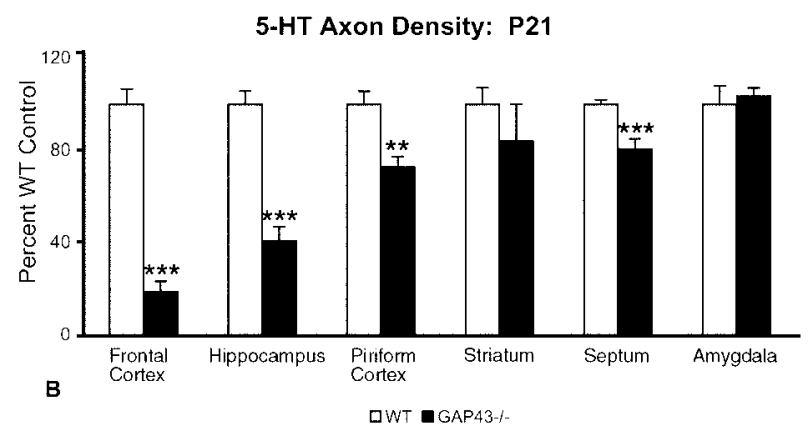

Figure 4. 5-HT axon densitometric analysis at $\mathrm{P} 7(A)$ and $\mathrm{P} 21(B)$ shows deficits in some but not all forebrain regions. Values are expressed as a percentage of the WT control mean. The density of 5-HT axons in the frontal cortex, hippocampus, and piriform cortex of GAP43-/- mice (black bars) is significantly reduced compared with WT mice (white bars) at both ages examined. In contrast, subcortical regions such as the amygdala and striatum show no significant differences in 5-HT innervation densities at both ages. 5-HT axon density in the septum is significantly reduced compared with $\mathrm{WT}$ at $\mathrm{P} 21$ but not at $\mathrm{P} 7 .{ }^{*} p \leq 0.05 ;{ }^{*} p \leq 0.01$; $* * * p \leq 0.001$.

causes a persistent and severe disruption in the pattern of ingrowth: some brain areas remain markedly devoid of 5-HT axons, whereas other regions are hyperinnervated. These differential effects on 5-HT axon ingrowth may have relevance to developmental disorders that involve regionally specific changes in monoamine expression, such as autism and schizophrenia.

We found that 5-HT axons largely fail to innervate the dorsal neocortex and hippocampus in the absence of GAP-43. These deficiencies are apparent on the day of birth $(\mathrm{P} 0)$ and remain evident at P21. GAP-43 heterozygote mice show an intermediate phenotype at all ages examined. Our findings that 5-HT cell numbers in the dorsal raphe nuclei (a major source of 5-HT axons in forebrain) are not significantly reduced in GAP-43-null mice indicate that GAP-43 influences primarily 5-HT axonal pathfinding and not cell differentiation. In contrast to the paucity of 5-HT fibers found in dorsal cortical areas of GAP-43-null mice, other forebrain areas, such as the striatum and amygdala, show normal innervation densities. Unexpectedly, we found dramatically increased densities of 5-HT axons in the VB thalamus of postnatal GAP43-/- mice.

Consistent with the immunocytochemical findings, levels of serotonin and its major metabolite 5-HIAA are reduced in the anterior and posterior cerebrum but are higher than normal in the brainstem of GAP-43-null mice. Likewise, levels of norepinephrine are decreased in the forebrain and increased in the brainstem of these mice, suggesting that this neurotransmitter system may also be adversely affected by decreased GAP-43 expression. GAP43-/- mice also show major defects in the corpus callosum
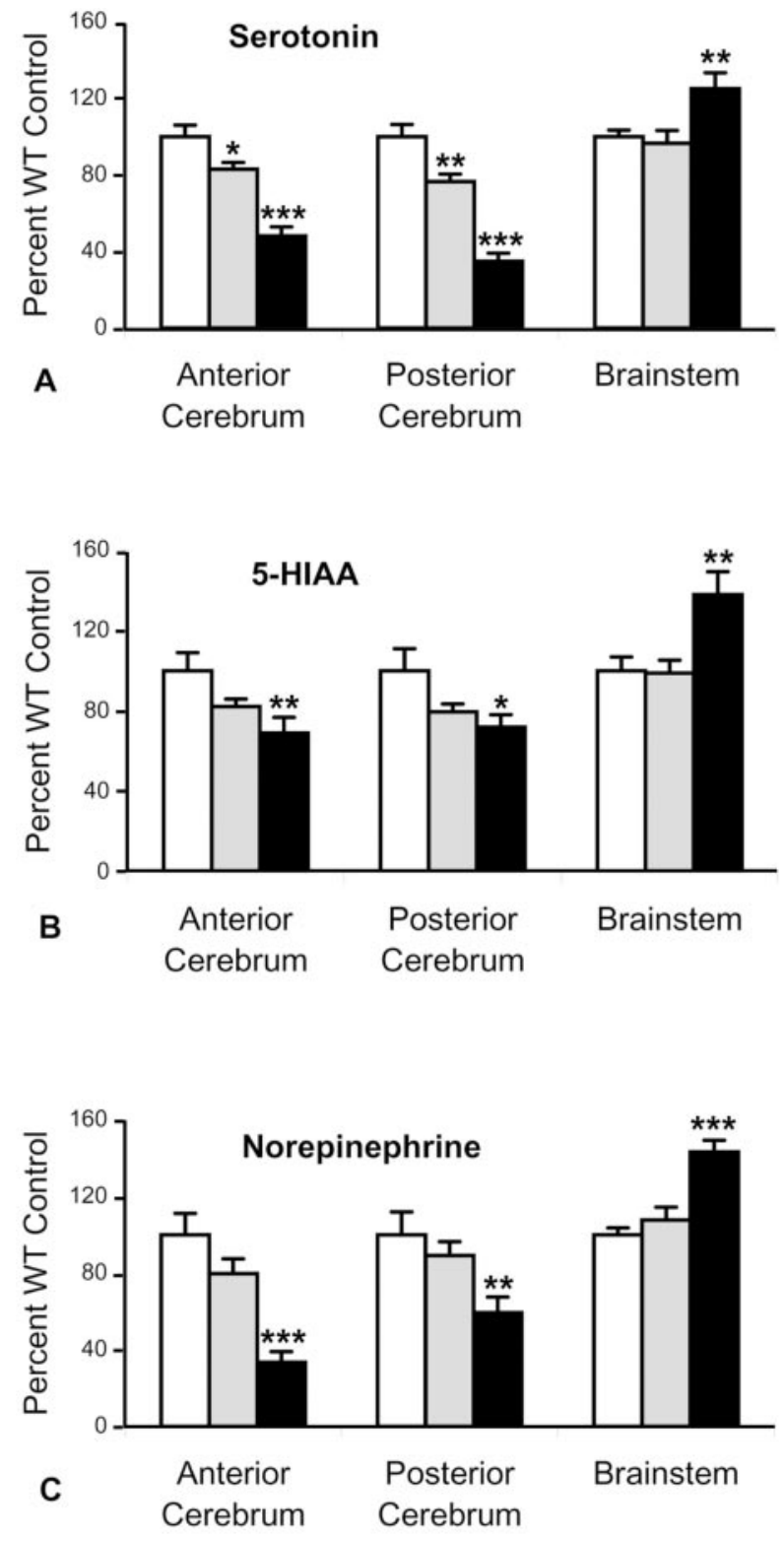

口WT $\square$ GAP43+/- 口GAP43-/-

Figure 5. Selected brain regions from P7 mice show gene-dosedependent effects on levels of serotonin, 5-HIAA, and norepinephrine as measured by HPLC. Values are expressed as percentage of WT controls. Serotonin levels are reduced by $52 \%$ in the anterior cerebrum and $65 \%$ in the posterior cerebrum and increased by $25 \%$ in the brainstem of GAP43-/- mice (black bars) compared with WT controls (white bars). GAP43 +/- mice (gray bars) show decreasing levels of serotonin in the anterior $(17 \%)$ and posterior $(23 \%)$ cerebrum $(A)$. Similar trends are observed for 5-HIAA levels. In GAP43-/- mice, 5-HIAA levels are reduced by 31 and $28 \%$ in the anterior and posterior cerebrum, respectively, whereas they increased by $38 \%$ in the brainstem $(B)$. Levels of norepinephrine also decrease by 66 and $41 \%$ in the anterior and posterior cerebrum, respectively, and increase by $43 \%$ in the brainstem $(C) .{ }^{*} p<$ $0.05 ; * * p<0.01 ; * * * p<0.001$.

and anterior commissure (Shen et al., 2002). We therefore conclude that GAP-43 is critical for the normal development of multiple brain pathways, including 5-HT projections from the brainstem to the cortex, hippocampus, and VB thalamus. 

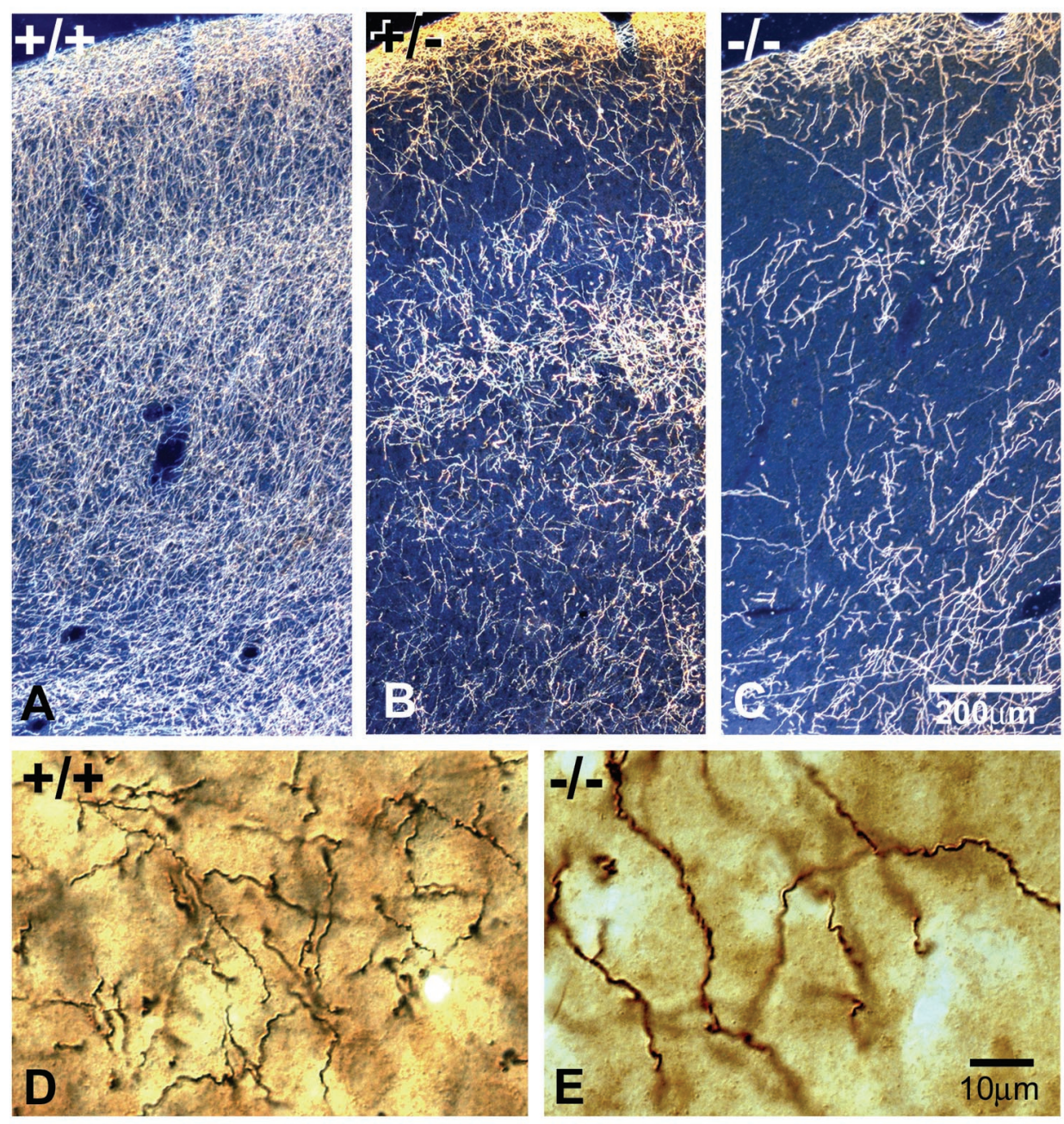

Figure 6. Alterations in the density and morphology of 5-HT axons persist in the frontal cortex at P21. High-magnification dark-field and bright-field photomicrographs show the pattern and morphology of 5-HT axons in GAP43-/- mice at P21. A fine, dense network of 5-HT axons innervates all cortical layers of the frontal cortex in WT mice $(A)$. A gene-dose-dependent reduction in the density of 5-HT axons is observed in GAP43+/- mice $(B)$ and GAP-43-null mice $(C)$. The morphology of 5-HT axons also varies according to genotype $(D, E)$. In WT mice, 5-HT axons are fine and highly branched $(A, D)$. In GAP43-/- mice $(C, E)$, 5-HT axons show less branching and are coarser than in WT animals. The morphology of 5 -HT axons in GAP43+/- mice is intermediate between that in WT and GAP43 $-/-$ mice $(B)$. Scale bars: $A-C, 200$ $\mu \mathrm{m} ; D, E, 10 \mu \mathrm{m}$.

\section{How does GAP-43 mediate its effects on 5-HT axon growth?}

Why is it that some forebrain areas are normally innervated but others are deficient in or overgrown with 5-HT afferents? Based on published models of GAP-43 function (Strittmatter et al., 1995; Benowitz and Routtenberg, 1997; Oestreicher et al., 1997), GAP-43 may interact with intracellular and extracellular signals to promote the proper pathfinding of 5-HT axons to a subset of forebrain targets. These signals could provide the underlying mechanism for axonal guidance. As evidence for this, CNS neurons from GAP43-/- mice are unable to respond to the neural cell adhesion molecules NCAM, L1, and N-cadherin, signals that normally induce neurite outgrowth (Meiri et al., 1998). However, integrin-mediated responses are unaffected, suggesting that GAP-43 is required for axonal navigation mediated by cell-to-cell contact. This model, if applicable to the development of 5-HT forebrain projections, predicts that 5-HT hypoinnervated forebrain areas such as the hippocampus and frontal, parietal, and occipital cortex require contact-mediated axonal guidance for normal 5-HT innervation, whereas normally innervated structures such as the striatum and amygdala do not.

Alternatively, the contrasting regional effects of GAP- 43 on the 5-HT projection may reflect differences in the topography or structural organization of the 5-HT system. For example, 5-HT axons may make cumulative targeting errors for regions more distant from the dorsal raphe and thus fail altogether to reach their most distal targets (i.e., the dorsal neocortex and hippocampus). This hypothesis is supported by the observed distribution of 5-HT axons in normal cortex, which show a rostral to caudal density gradient. A second possibility is that targeting errors by other afferent systems, such as those from thalamic or noradrenergic nuclei, may prevent the induction of markers or "guidepost" molecules required for normal 5-HT axon pathfinding.

The 5-HT hyperinnervation in the VB thalamus of GAP-43null mice may represent a compensatory sprouting response from 5-HT axons that are unable to locate their targets in the cortex and hippocampus, because single dorsal raphe cells send collateral projections to the thalamus and somatosensory cortex (Kirifides et al., 2001). Additional studies will be needed to fully understand the role of GAP-43 in the development of monoaminergic projections to forebrain and the adaptive responses of these pathways to decreased GAP-43 expression.

\section{The role of GAP-43 in the developing barrel field}

In the barrel field of the SI cortex, TCAs transiently express 5-HT markers and are disrupted in GAP-43-null mice (Maier et al., 1999). Therefore, could the loss of 5-HT-positive TCAs account for the markedly reduced 5-HT innervation seen in SI cortex? This is unlikely, because other cortical regions that do not receive TCA input are also largely devoid of 5-HT axons in these mice 


\section{P7}
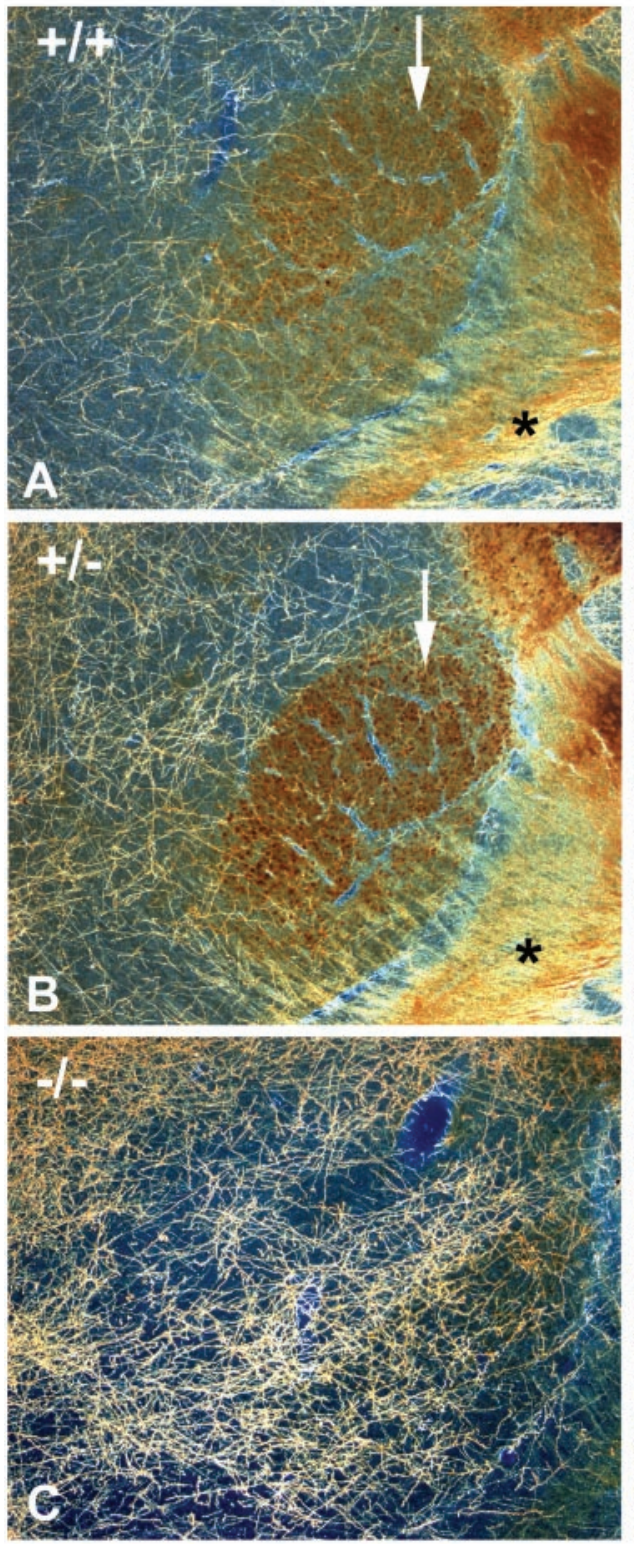

P21
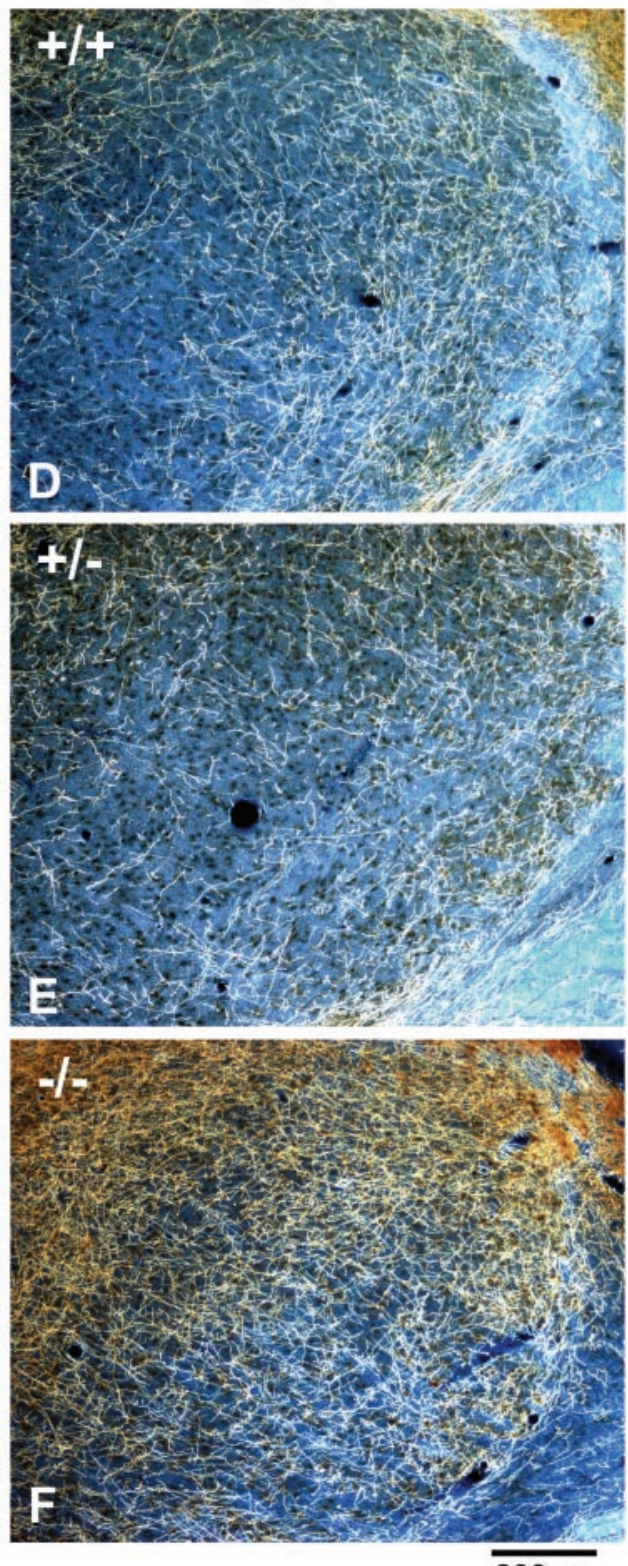

Figure 7. At P7 and P21, 5-HT axons hyperinnervate the VB thalamus in GAP43-/- mice. Dark-field photomicrographs of coronal sections show 5-HT immunostaining in the thalamus of $\mathrm{P} 7(A-C)$ and P21 $(D-F)$ mice. At P7, 5-HT axon density is dramatically higher in the VB thalamus of GAP43-/- mice $(C)$ than in WT mice $(A)$ and GAP43+/- mice $(B)$. At $\mathrm{P} 21,5-\mathrm{HT}$ axon density remains elevated in GAP43-/- mice $(F)$ relative to GAP43+/ - mice $(E)$ and WT mice $(D)$. Interestingly, 5-HT immunostaining of barreloid patches (arrows) and thalamocortical axons (asterisks) observed in WT $(A)$ and heterozygote $(B)$ animals at $\mathrm{P} 7$ is largely absent in GAP43-/- mice $(C)$. Scale bar, $200 \mu \mathrm{m}$.

(e.g., the hippocampus and supragranular and infragranular layers of dorsal neocortex). Furthermore, the changes in 5-HT axon density persist at $\mathrm{P} 21$, a time at which the TCAs no longer exhibit a 5-HT phenotype.

Conversely, could the lack of 5-HT ingrowth to the somatosensory cortex contribute to the disrupted barrel map found in GAP-43-null mice? Serotonin depletion delays development of several cortical layers (Osterheld-Haas and Hornung, 1996), generating a mismatch in the maturation of cortical neurons and their afferents. Studies by us and others also have demonstrated that ablating the 5-HT input neonatally with 5-HT neurotoxins delays the appearance of TCA patterning in the barrel field (Blue et al., 1991) and ultimately leads to decreases in the size of the barrels themselves (Bennett-Clarke et al., 1994; Persico et al., 2000). Nonetheless, the barrel field forms after the neonatal 5-HT lesions. Thus, although the neonatal removal of 5-HT afferents to the cortex could contribute to a disordered barrel map by delay- ing cortical maturation and/or TCA outgrowth, it cannot fully explain the barrel-less phenotype found in GAP-43-null mice. However, in the homozygous GAP43-/- mice, GAP-43 is missing from early gestation. In fact, the 5 -HT projection to the cortex is defective on the day of birth, suggesting that there are prenatal effects of the absence of GAP-43. Therefore, the continuous absence of GAP-43 throughout prenatal and postnatal life could account for the more severe effects on barrel formation observed in GAP-43-null mice.

Interestingly, excessive (as opposed to insufficient) levels of extracellular serotonin appear to be more detrimental to barrel formation and can lead to the barrel-less pattern, as seen in monoamine oxidase A and SERT knock-out mice (Cases et al., 1996; Vitalis et al., 1998; Persico et al., 2001). Although our findings indicate a reduced 5-HT innervation to barrel cortex in GAP-43-null mice, there is a striking hyperinnervation of the VB thalamus in these mice, similar to the high levels of serotonin 
Density of 5-HT Axons: VB Thalamus

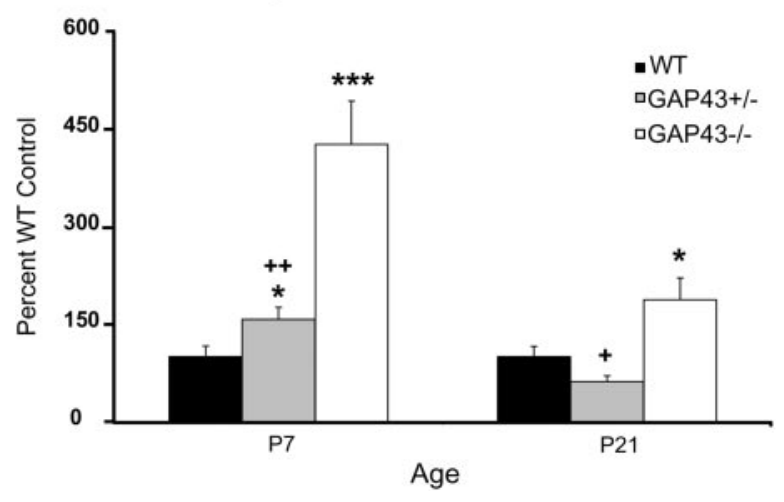

Figure 8. Densitometric analysis of the VB thalamus at P7 and P21 shows persistent increases in 5-HT axon density in GAP43-/- mice. Values are expressed as a percentage of the WT control mean. The density of 5-HT axons in the VB thalamus of GAP43-/- mice (white bars; 427\%) and GAP43+/- mice (gray bars; 158\%) is significantly increased compared with WT mice (black bars; 100\%) at P7. 5-HT axon density remains elevated in GAP43-/- mice ( $158 \%)$ compared with WT and heterozygote mice at P21. ${ }^{*} p \leq 0.05,{ }^{* * *} p \leq 0.001$ relative to WT; ${ }^{+} p \leq 0.05,{ }^{++} p \leq 0.01$ for GAP43+/- versus GAP43-/- comparisons; not significant, GAP43+/- versus WT at P21.

found in the VB complex of monoamine oxidase A and SERT knock-out mice (Salichon et al., 2001). Thus, abnormal patterns of 5-HT ingrowth during early development (i.e., an excessive 5-HT innervation to the VB thalamus along with the lack of ingrowth to the cortex) may be detrimental to cortical morphogenesis.

In conclusion, our results indicate that GAP-43 plays a crucial role in the development of 5-HT projections to selected regions of the forebrain. These findings may have relevance to developmental disorders, such as autism, that show severe alterations in sensory processing and in the development of the 5-HT system (Chugani et al., 1999). Therefore, understanding the mechanisms by which GAP-43 regulates the ingrowth of 5-HT axons to the forebrain may shed light on the cellular machinery important in axonal pathfinding and serotonin-related developmental disorders.

\section{REFERENCES}

Alonso G, Ridet JL, Oestreicher AB, Gispen WH, Privat A (1995) B-50 (GAP-43) immunoreactivity is rarely detected within intact catecholaminergic and serotonergic axons innervating the brain and spinal cord of the adult rat, but is associated with these axons following lesion. Exp Neurol 134:35-48.

Andrews AM, Ladenheim B, Epstein CJ, Cadet JL, Murphy DL (1996) Transgenic mice with high levels of superoxide dismutase activity are protected from the neurotoxic effects of 2'-NH2-MPTP on serotonergic and noradrenergic nerve terminals. Mol Pharmacol 50:1511-1519.

Azmitia EC, Dolan K, Whitaker-Azmitia PM (1990) S-100 $\beta$ but not NGF, EGF, insulin or calmodulin is a CNS serotonergic growth factor. Brain Res 516:354-356.

Baumgarten HG, Grozdanovic Z (1995) Psychopharmacology of central serotonergic systems. Pharmacopsychiatry 28 [Suppl 2]:73-79.

Bendotti C, Servadio A, Samanin R (1991) Distribution of GAP-43 mRNA in the brain stem of adult rats as evidenced by in situ hybridization: localization within monoaminergic neurons. J Neurosci 11:600-607.

Bennett-Clarke CA, Leslie MJ, Lane RD, Rhoades RW (1994) Effect of serotonin depletion on vibrissa-related patterns of thalamic afferents in the rat's somatosensory cortex. J Neurosci 14:7594-7607.

Bennett-Clarke CA, Chiaia NL, Rhoades RW (1996) Thalamocortical afferents in rat transiently express high-affinity serotonin uptake sites. Brain Res 733:301-306.

Benowitz LI, Routtenberg A (1997) GAP-43: an intrinsic determinant of neuronal development and plasticity. Trends Neurosci 20:84-91.

Benowitz LI, Apostolides PJ, Perrone-Bizzozero N, Finklestein SP,
Zwiers H (1988) Anatomical distribution of the growth-associated protein GAP-43/B-50 in the adult rat brain. J Neurosci 8:339-352.

Blue ME, Erzurumlu RS, Jhaveri S (1991) A comparison of pattern formation by thalamocortical and serotonergic afferents in the rat barrel field cortex. Cereb Cortex 1:380-389.

Cases O, Vitalis T, Seif I, De Maeyer E, Sotelo C, Gaspar P (1996) Lack of barrels in the somatosensory cortex of monoamine oxidase A-deficient mice: role of a serotonin excess during the critical period. Neuron 16:297-307.

Chugani DC, Muzik O, Behen M, Rothermel R, Janisse JJ, Lee J, Chugani HT (1999) Developmental changes in brain serotonin synthesis capacity in autistic and nonautistic children. Ann Neurol 45:287-295.

D'Amato RJ, Blue ME, Largent BL, Lynch DR, Ledbetter DJ, Molliver ME, Snyder SH (1987) Ontogeny of the serotonergic projection to rat neocortex: transient expression of a dense innervation to primary sensory areas. Proc Natl Acad Sci USA 84:4322-4326.

Dekker LV, De Graan PN, Versteeg DH, Oestreicher AB, Gispen WH (1989a) Phosphorylation of B-50 (GAP43) is correlated with neurotransmitter release in rat hippocampal slices. J Neurochem 52:24-30.

Dekker LV, De Graan PN, Oestreicher AB, Versteeg DH, Gispen WH (1989b) Inhibition of noradrenaline release by antibodies to B-50 (GAP-43). Nature 342:74-76.

Dori I, Dinopoulos A, Blue ME, Parnavelas JG (1996) Regional differences in the ontogeny of the serotonergic projection to the cerebral cortex. Exp Neurol 138:1-14.

Erzurumlu RS, Jhaveri S, Benowitz LI (1990) Transient patterns of GAP-43 expression during the formation of barrels in the rat somatosensory cortex. J Comp Neurol 292:443-456.

Gianotti C, Nunzi MG, Gispen WH, Corradetti R (1992) Phosphorylation of the presynaptic protein B-50 (GAP-43) is increased during electrically induced long-term potentiation. Neuron 8:843-848.

Halaris AE, Jones BE, Moore RY (1976) Axonal transport in serotonin neurons of the midbrain raphe. Brain Res 107:555-574.

Haring JH, Hagan A, Olson J, Rodgers B (1993) Hippocampal serotonin levels influence the expression of S100 beta detected by immunocytochemistry. Brain Res 631:119-123.

Haruta T, Takami N, Ohmura M, Misumi Y, Ikehara Y (1997) $\mathrm{Ca}^{2+}$. dependent interaction of the growth-associated protein GAP-43 with the synaptic core complex. Biochem J 325:455-463.

Hen R (1996) Mean genes. Neuron 16:17-21.

Jacobson RD, Virag I, Skene JH (1986) A protein associated with axon growth, GAP-43, is widely distributed and developmentally regulated in rat CNS. J Neurosci 6:1843-1855.

Kirifides ML, Simpson KL, Lin RC, Waterhouse BD (2001) Topographic organization and neurochemical identity of dorsal raphe neurons that project to the trigeminal somatosensory pathway in the rat. J Comp Neurol 435:325-340.

Kitt CA, Struble RG, Cork LC, Mobley WC, Walker LC, Joh TH, Price DL (1985) Catecholaminergic neurites in senile plaques in prefrontal cortex of aged nonhuman primates. Neuroscience 16:691-699.

Kosofsky BE, Molliver ME (1987) The serotoninergic innervation of cerebral cortex: different classes of axon terminals arise from dorsal and median raphe nuclei. Synapse 1:153-168.

Kruger K, Tam AS, Lu C, Sretavan DW (1998) Retinal ganglion cell axon progression from the optic chiasm to initiate optic tract development requires cell autonomous function of GAP-43. J Neurosci 18:5692-5705.

Lidov HG, Molliver ME (1982a) Immunohistochemical study of the development of serotonergic neurons in the rat CNS. Brain Res Bull 9:559-604.

Lidov HG, Molliver ME (1982b) An immunohistochemical study of serotonin neuron development in the rat: ascending pathways and terminal fields. Brain Res Bull 8:389-430.

Linden DJ, Wong KL, Sheu FS, Routtenberg A (1988) NMDA receptor blockade prevents the increase in protein kinase $\mathrm{C}$ substrate (protein F1) phosphorylation produced by long-term potentiation. Brain Res 458:142-146.

Lovinger DM, Colley PA, Akers RF, Nelson RB, Routtenberg A (1986) Direct relation of long-term synaptic potentiation to phosphorylation of membrane protein $\mathrm{F} 1$, a substrate for membrane protein kinase C. Brain Res 399:205-211.

Lyons WE, Mamounas LA, Ricaurte GA, Coppola V, Reid SW, Bora SH, Wihler C, Koliatsos VE, Tessarollo L (1999) Brain-derived neurotrophic factor-deficient mice develop aggressiveness and hyperphagia in conjunction with brain serotonergic abnormalities. Proc Natl Acad Sci USA 96:15239-15244.

Maier DL, Mani S, Donovan SL, Soppet D, Tessarollo L, McCasland JS, Meiri KF (1999) Disrupted cortical map and absence of cortical barrels in growth-associated protein (GAP)-43 knockout mice. Proc Natl Acad Sci USA 96:9397-9402.

Mamounas LA, Mullen CA, O'Hearn E, Molliver ME (1991) Dual serotoninergic projections to forebrain in the rat: morphologically distinct 5-HT axon terminals exhibit differential vulnerability to neurotoxic amphetamine derivatives. J Comp Neurol 314:558-586. 
Mamounas LA, Blue ME, Siuciak JA, Altar CA (1995) Brain-derived neurotrophic factor promotes the survival and sprouting of serotonergic axons in rat brain. J Neurosci 15:7929-7939.

Mamounas LA, Altar CA, Blue ME, Kaplan DR, Tessarollo L, Lyons WE (2000) BDNF promotes the regenerative sprouting, but not survival, of injured serotonergic axons in the adult rat brain. J Neurosci 20:771-782.

Mann JJ (1998) The neurobiology of suicide. Nat Med 4:25-30.

McGuire CB, Snipes GJ, Norden JJ (1988) Light-microscopic immunolocalization of the growth- and plasticity-associated protein GAP-43 in the developing rat brain. Brain Res 469:277-291.

Meiri KF, Saffell JL, Walsh FS, Doherty P (1998) Neurite outgrowth stimulated by neural cell adhesion molecules requires growthassociated protein-43 (GAP-43) function and is associated with GAP-43 phosphorylation in growth cones. J Neurosci 18:10429-10437.

Molliver ME (1987) Serotonergic neuronal systems: what their anatomic organization tells us about function. J Clin Psychopharmacol 7:3S-23S.

Moore RY, Halaris AE, Jones BE (1978) Serotonin neurons of the midbrain raphe: ascending projections. J Comp Neurol 180:417-438.

Neve RL, Perrone-Bizzozero NI, Finklestein S, Zwiers H, Bird E, Kurnit DM, Benowitz LI (1987) The neuronal growth-associated protein GAP-43 (B-50, F1): neuronal specificity, developmental regulation and regional distribution of the human and rat mRNAs. Brain Res 388:177-183.

Neve RL, Coopersmith R, McPhie DL, Santeufemio C, Pratt KG, Murphy CJ, Lynn SD (1998) The neuronal growth-associated protein GAP-43 interacts with rabaptin-5 and participates in endocytosis. J Neurosci 18:7757-7767.

Oestreicher AB, Gispen WH (1986) Comparison of the immunocytochemical distribution of the phosphoprotein B-50 in the cerebellum and hippocampus of immature and adult rat brain. Brain Res 375:267-279.

Oestreicher AB, De Graan PN, Gispen WH, Verhaagen J, Schrama LH (1997) B-50, the growth associated protein-43: modulation of cell morphology and communication in the nervous system. Prog Neurobiol 53:627-686.

Osterheld-Haas MC, Hornung JP (1996) Laminar development of the mouse barrel cortex: effects of neurotoxins against monoamines. Exp Brain Res 110:183-195.

Persico AM, Altamura C, Calia E, Puglisi-Allegra S, Ventura R, Lucchese F, Keller F (2000) Serotonin depletion and barrel cortex development: impact of growth impairment vs. serotonin effects on thalamocortical endings. Cereb Cortex 10:181-191.

Persico AM, Mengual E, Moessner R, Hall FS, Revay RS, Sora I, Arellano J, DeFelipe J, Gimenez-Amaya JM, Conciatori M, Marino R,
Baldi A, Cabib S, Pascucci T, Uhl GR, Murphy DL, Lesch KP, Keller F, Hall SF (2001) Barrel pattern formation requires serotonin uptake by thalamocortical afferents, and not vesicular monoamine release. J Neurosci 21:6862-6873.

Ramakers GM, De Graan PN, Urban IJ, Kraay D, Tang T, Pasinelli P, Oestreicher AB, Gispen WH (1995) Temporal differences in the phosphorylation state of pre- and postsynaptic protein kinase $C$ substrates B-50/GAP-43 and neurogranin during long-term potentiation. J Biol Chem 270:13892-13898.

Rhoades RW, Bennett-Clarke CA, Chiaia NL, White FA, MacDonald GJ, Haring JH, Jacquin MF (1990) Development and lesion induced reorganization of the cortical representation of the rat's body surface as revealed by immunocytochemistry for serotonin. J Comp Neurol 293:190-207.

Rubenstein JL (1998) Development of serotonergic neurons and their projections. Biol Psychiatry 44:145-150.

Salichon N, Gaspar P, Upton AL, Picaud S, Hanoun N, Hamon M, De Maeyer EE, Murphy DL, Mossner R, Lesch KP, Hen R, Seif I (2001) Excessive activation of serotonin (5-HT) $1 \mathrm{~B}$ receptors disrupts the formation of sensory maps in monoamine oxidase A and 5-HT transporter knock-out mice. J Neurosci 21:884-896.

Shen Y, Mani S, Donovan SL, Schwob JE, Meiri KF (2002) Growthassociated protein-43 is required for commissural axon guidance in the developing vertebrate nervous system. J Neurosci 22:239-247.

Sretavan DW, Kruger K (1998) Randomized retinal ganglion cell axon routing at the optic chiasm of GAP-43-deficient mice: association with midline recrossing and lack of normal ipsilateral axon turning. J Neurosci 18:10502-10513.

Strittmatter SM, Fankhauser C, Huang PL, Mashimo H, Fishman MC (1995) Neuronal pathfinding is abnormal in mice lacking the neuronal growth cone protein GAP-43. Cell 80:445-452.

Van Hartesveldt C, Moore B, Hartman BK (1986) Transient midline raphe glial structure in the developing rat. J Comp Neurol 253:174-184.

Vitalis T, Cases O, Callebert J, Launay JM, Price DJ, Seif I, Gaspar P (1998) Effects of monoamine oxidase A inhibition on barrel formation in the mouse somatosensory cortex: determination of a sensitive developmental period. J Comp Neurol 393:169-184.

Wallace JA, Lauder JM (1983) Development of the serotonergic system in the rat embryo: an immunocytochemical study. Brain Res Bull 10:459-479.

Wotherspoon G, Lopez-Costa JJ, Michael GJ, Priestley JV (1997) Constitutive expression of calmodulin-binding phosphoprotein GAP-43 in rat serotonergic and noradrenergic cell groups which project to the spinal cord. Neurochem Res 22:985-993. 